\title{
Inhibition of Epstein-Barr Virus Lytic Reactivation by the Atypical Antipsychotic Drug Clozapine
}

\author{
Abbie G. Anderson, Cullen B. Gaffy, Joshua R. Weseli and Kelly L. Gorres * \\ Department of Chemistry \& Biochemistry, University of Wisconsin-La Crosse, 1725 State St., La Crosse, WI 54601, \\ USA; anderson.abbie@uwlax.edu (A.G.A.); gaffy.cullen@uwlax.edu (C.B.G.); weseli.joshua@uwlax.edu (J.R.W.) \\ * Correspondence: kgorres@uwlax.edu; Tel.: +1-608-785-5284
}

Received: 2 April 2019; Accepted: 15 May 2019; Published: 17 May 2019

\begin{abstract}
Epstein-Barr virus (EBV), a member of the Herpesviridae family, maintains a lifelong latent infection in human B cells. Switching from the latent to the lytic phase of its lifecycle allows the virus to replicate and spread. The viral lytic cycle is induced in infected cultured cells by drugs such as sodium butyrate and azacytidine. Lytic reactivation can be inhibited by natural products and pharmaceuticals. The anticonvulsant drugs valproic acid and valpromide inhibit EBV in Burkitt lymphoma cells. Therefore, other drugs that treat neurological and psychological disorders were investigated for effects on EBV lytic reactivation. Clozapine, an atypical antipsychotic drug used to treat schizophrenia and bipolar disorder, was found to inhibit the reactivation of the EBV lytic cycle. Levels of the viral lytic genes BZLF1, BRLF1, and BMLF1 were decreased by treatment with clozapine in induced Burkitt lymphoma cells. The effects on viral gene expression were dependent on the dose of clozapine, yet cells were viable at an inhibitory concentration of clozapine. One metabolite of clozapine-desmethylclozapine-also inhibited EBV lytic reactivation, while another metabolite—clozapine-N-oxide-had no effect. These drugs may be used to study cellular pathways that control the viral lytic switch in order to develop treatments for diseases caused by EBV.
\end{abstract}

Keywords: Epstein-Barr virus; herpes viruses; lytic gene expression; Burkitt lymphoma cells; clozapine; antipsychotic drug; antiviral drug

\section{Introduction}

Epstein-Barr virus (EBV) is a member of the Herpesviridae family and causes infectious mononucleosis. EBV was the first virus discovered to cause cancer in humans. EBV is associated with Burkitt lymphoma, Hodgkin lymphoma, gastric carcinoma, nasopharyngeal carcinoma, and post-transplant lymphoproliferative disorder. After infection with EBV, the virus maintains a lifelong latent infection within the host. The expression of a few viral genes during the latent phase allows the virus to persist. The viral life cycle alternates between two phases: the latent and the lytic phases. During the lytic phase the virus replicates and spreads among cells and hosts.

The lytic phase of the virus can be triggered in latently infected cultured cells by various inducing agents [1]. Sodium butyrate (NaB), a short-chain fatty acid that inhibits histone deacetylases, promotes the reactivation of the lytic cycle (Figure 1) [2]. Although quite different in chemical structure from butyrate, the DNA methyltransferase inhibitors 5-azacytidine and 5-aza-2'-deoxycytidine (dAzaC), and the protein kinase $\mathrm{C}$ agonist 12-O-tetradecanoylphorbol-13-acetate (TPA) also induce the EBV lytic cycle [3]. Molecules with diverse structures inhibit reactivation of the EBV lytic cycle by these inducing agents. Some inhibitors are structurally similar to butyrate. Valproate (valproic acid, VPA) and valpromide (VPM) prevent the virus from reactivating into the lytic cycle in Burkitt lymphoma cells $[4,5]$. VPA and VPM are used clinically as anticonvulsant and mood-stabilizing drugs. 

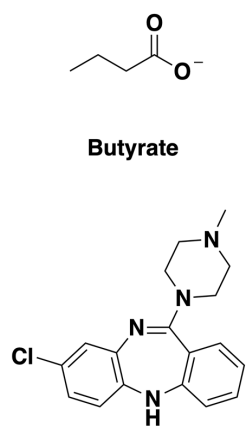

Clozapine

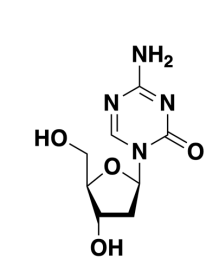

5-Aza-2'-deoxycytidine

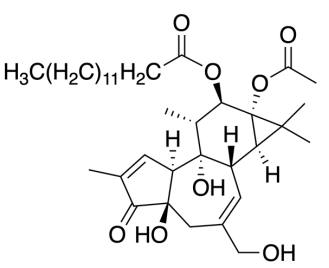

TPA

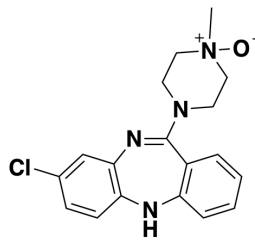

Clozapine-N-oxide

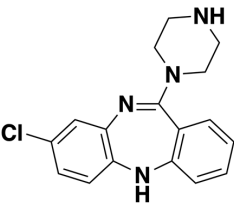

N-Desmethylclozapine

Figure 1. Structures of drugs tested for effects on Epstein-Barr virus (EBV) lytic reactivation: sodium butyrate (NaB), 5-aza-2'-deoxycytidine (dAzaC), 12-O-tetradecanoylphorbol-13-acetate (TPA), clozapine, clozapine-N-oxide, and N-desmethylclozapine.

To determine if there is any commonality between the effects of VPA in neurological and psychological conditions and in blocking EBV reactivation, we investigated other drugs used to treat neurological conditions for effects on the EBV lytic cycle. Clozapine, a member of the dibenzodiazepine class, is used in the treatment of schizophrenia and bipolar disorder (Figure 1). Clozapine (Clozaril ${ }^{\mathrm{TM}}$ ) was the first atypical, or second-generation, antipsychotic drug developed [6]. It is therapeutically effective at treating schizophrenic patients who are resistant to typical antipsychotic drugs [7]. We demonstrate here that clozapine and one of its metabolites inhibit the induction of EBV lytic cycle gene expression.

\section{Materials and Methods}

\subsection{Chemicals}

Sodium butyrate $(\mathrm{NaB} ;>98 \%$, Aldrich) and 5-aza-2'-deoxycytidine (dAzaC; Chem-Impex, Wood Dale, IL, USA) were dissolved in water. Clozapine ( $>99 \%$, ApexBio, Houston, TX, USA), clozapine-N-oxide ( $>98 \%$, ApexBio), N-desmethylclozapine (98\%, Santa Cruz Biotech, Santa Cruz, CA, USA), and TPA (99\%, AdipoGen, San Diego, CA, USA) were dissolved in DMSO. Drugs were used at concentrations noted in the figures and legends.

\subsection{Cell Culture and Chemical Treatments}

The HH514-16 human Burkitt lymphoma [8] and Raji cells were cultured in RPMI $1640+$ glutamine supplemented with $8 \% \mathrm{FBS}$, penicillin $(50 \mathrm{U} / \mathrm{mL})$, streptomycin $(50 \mathrm{U} / \mathrm{mL})$, and amphotericin $\mathrm{B}(1 \mu \mathrm{g} / \mathrm{mL})$. Cells were grown at $37^{\circ} \mathrm{C}$ under $5 \% \mathrm{CO}_{2}$. Cells were subcultured to $3-4 \times 10^{5}$ cells $/ \mathrm{mL}$ two days prior to the experiment. The experiments started with $1 \times 10^{6}$ cells $/ \mathrm{mL}$ in RPMI 1640 supplemented with $1 \%$ FBS. Cells were harvested $24 \mathrm{~h}$ post-treatment. Cell death was measured by trypan blue staining and counting using a hemacytometer. In all experiments that investigated EBV reactivation, $>90 \%$ of the cells were viable.

\subsection{Lytic Reactivation by RT-qPCR}

Quantitative reverse transcription polymerase chain reaction (RT-qPCR) was used to measure lytic gene expression. RNA was extracted from cells using the ReliaPrep system (Promega, Madison, WI, USA). Primers used to detect the expression of BZLF1 were AGCAGACATTGGTGTTCCAC (forward) and CATTCCTCCAGCGATTCTG (reverse); for BRLF1 they were CCATACAGGACACAACACCTCA (forward) and ACTCCCGGCTGTAAATTCCT (reverse); and for BMLF1, GGAGGAGGATGAAGA 
TCCAA (forward) and TTTCTGGGAATCACAAACGA (reverse). The RT-qPCR utilized the iScript SYBR green RT-qPCR kit (Bio-Rad). Expression levels were normalized to 18S RNA, present at consistent levels among cells.

\subsection{Statistical Analysis}

Data are reported as the average of the number of biological replicates noted in the figure legends. The values are displayed as the mean \pm standard deviation. Values are either the fold increase compared to the untreated control or the percent of maximum lytic reactivation by the inducing agent. To determine the differences among treatments, $p$-values were calculated using a paired $t$-test in R 3.3.3 of the quantitation cycle $(\Delta \mathrm{Cq})$ values from RT-qPCR. Significant differences were considered when the $p$-value $<0.05$.

\section{Results}

\subsection{Clozapine Blocked the Induction of EBV Lytic Genes}

We investigated the response of EBV to the atypical antipsychotic drug clozapine. The experiments were performed in the HH514-16 EBV-positive Burkitt lymphoma cell line, derived from Jijoye and P3HR1 cells [8]. The degree of viral reactivation was measured by expression of the viral BZLF1 gene, an immediate early gene that encodes a transcription transactivator [9]. The expression of BZLF1 initiates the reactivation of the Epstein-Barr virus lytic cycle. Treatment of cells with the known inducing agent $\mathrm{NaB}$ for $24 \mathrm{~h}$ caused an approximately 200-fold increase in BZLF1 expression compared to untreated cells (Figure 2A). Clozapine alone did not induce BZLF1 expression or decrease basal levels of expression. When clozapine $(50 \mu \mathrm{M})$ was added to cells with NaB, BZLF1 induction was significantly decreased (Figure 2A). Induction of another EBV immediate early gene, BRLF1, was also significantly inhibited by clozapine (Figure 2B). To determine if the reduction in these viral immediate early genes by clozapine affects the expression of a downstream lytic gene, levels of the BMLF1 gene that encodes an mRNA export factor were measured [10,11]. Expression of BMLF1 was induced in cells treated with butyrate, as expected. The addition of clozapine plus butyrate decreased BMLF1 expression to levels comparable to untreated cells (Figure 2C).
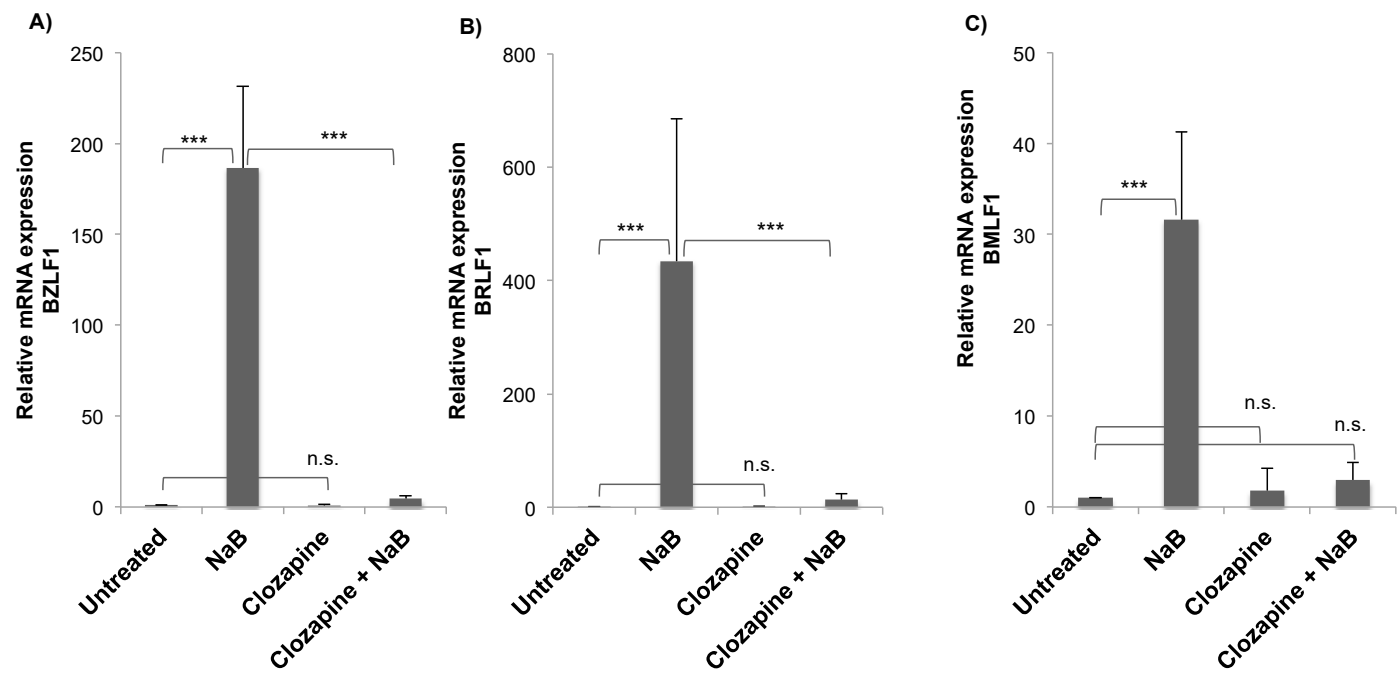

Figure 2. Clozapine inhibited the induction of Epstein-Barr virus (EBV) lytic gene expression. Expression of each gene, (A) BZLF1, (B) BRLF1, (C) BMLF1, was measured by RT-qPCR in untreated HH514-16 cells compared to treatment for $24 \mathrm{~h}$ with $\mathrm{NaB}(3 \mathrm{mM})$, clozapine $(50 \mu \mathrm{M})$, or the combination of $\mathrm{NaB}$ and clozapine. Values are the average fold induction compared to the untreated control of four or more biological replicates. Error bars show the standard deviation. Differences with a $p$-value $<0.001$ are denoted with ${ }^{* *}, p$-value $<0.01$ with ${ }^{* *}$, and not significantly different ( $p$-value $>0.05$ ) with n.s. 


\subsection{Dose-Dependent Inhibition by Clozapine}

The effects of varying concentrations of clozapine on the reactivation of EBV into the lytic cycle were tested. Clozapine at 2, 10, or $50 \mu \mathrm{M}$ did not induce BZLF1 viral gene expression in the HH514-16 Burkitt lymphoma cells compared to untreated cells (Figure 3). When added with butyrate, lower concentrations of clozapine (i.e., 2 or $10 \mu \mathrm{M}$ ) inhibited BZLF1 expression by $\sim 40 \%-50 \%$ compared to the level reached in cells treated with only NaB. Clozapine at $50 \mu \mathrm{M}$ inhibited lytic reactivation by $\mathrm{NaB}$ by $>95 \%$ compared to the reactivation seen with $\mathrm{NaB}$ alone.

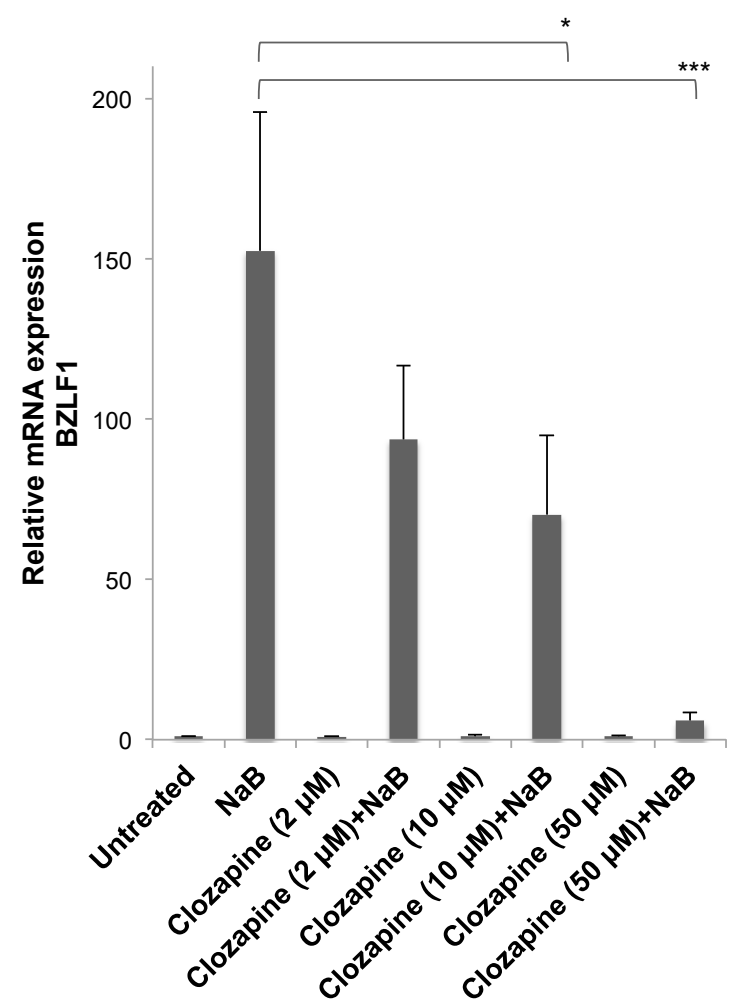

Figure 3. Inhibition of Epstein-Barr virus (EBV) lytic reactivation by clozapine was dose dependent. Clozapine $(2,10$, and $50 \mu \mathrm{M})$ was tested in the presence and absence of $\mathrm{NaB}(3 \mathrm{mM})$ for the effects on BZLF1 expression in HH514-16 cells. Values are the average of seven biological replicates. There was no significant difference between untreated cells and cells treated with only clozapine at any concentration. Differences in BZLF1 expression comparing cells treated with butyrate in the absence and presence of clozapine are marked with * for $p$-value $<0.05$ and ${ }^{* * *}$ for a $p$-value $<0.001$.

The concentrations of clozapine that inhibited EBV lytic reactivation, up to $50 \mu \mathrm{M}$, did not limit cell growth or the percentage of dead cells when treated for $24 \mathrm{~h}$ (Figure 4 ). With $50 \mu \mathrm{M}$ clozapine, cells remained $>93 \% \pm 4 \%$ viable $(n=6)$ after $48 \mathrm{~h}$ and $88 \% \pm 3 \%$ viable $(n=3)$ after $72 \mathrm{~h}$ of treatment. Toxicity was observed within $24 \mathrm{~h}$ when the clozapine concentration reached $100 \mu \mathrm{M}$. Cell toxicity with $100 \mu \mathrm{M}$ clozapine varied widely among experiments, but the average of 12 replicates resulted in $\sim 40 \%$ cell death. When the clozapine concentration reached $200 \mu \mathrm{M}$, nearly all of the cells were dead after $24 \mathrm{~h}$ in all experiments. 


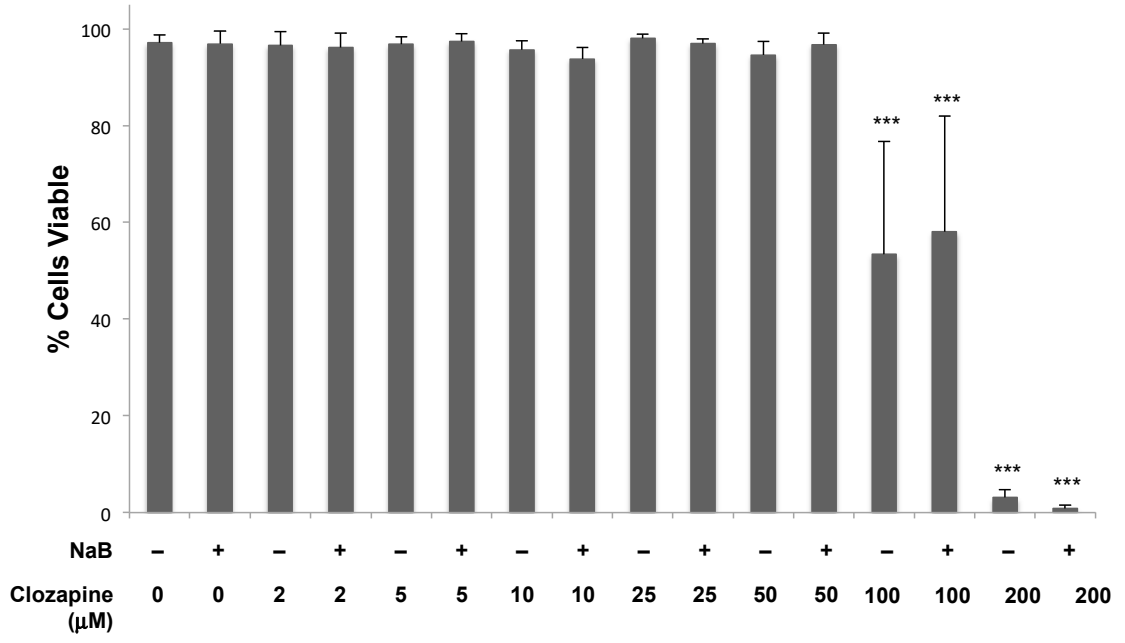

Figure 4. Cells remained viable when treated with $50 \mu \mathrm{M}$ clozapine for $24 \mathrm{~h}$. Clozapine was tested at concentrations from $2-200 \mu \mathrm{M}$ in the presence and absence of $\mathrm{NaB}(3 \mathrm{mM})$ for the effects on the viability of Burkitt lymphoma cells. Data from four or more biological replicates were averaged, and error bars represent the standard deviation. Conditions are not marked unless significantly different than untreated cells. Differences with a $p$-value $<0.001$ are denoted with ${ }^{* * *}$.

\subsection{Clozapine Decreased EBV Lytic Induction by $d A z a C$ and TPA}

Like butyrate, 5-aza-2'-deoxycytidine (dAzaC) also induces lytic gene expression in HH514-16 cells [3]. Sold under the drug name Decitabine, dAzaC is a DNA methyltransferase inhibitor that is thought to activate EBV by a different mechanism than butyrate [1]. dAzaC $(10 \mu \mathrm{M})$ was not as potent an activator of BZLF1 expression ( 40-fold) as butyrate in HH514-16 cells, but activated the expression of BZLF1 significantly compared to untreated cells (Figure 5). The addition of clozapine (50 $\mu \mathrm{M})$ at the same time as $\mathrm{dAzaC}$ resulted in a $60 \%$ decrease in BZLF1 expression compared to $\mathrm{dAzaC}$ alone. Clozapine decreased EBV lytic reactivation stimulated by two different lytic inducing agents, but the effectiveness varied. This may have been due to the different mechanisms used by the inducing agents and the shorter length of exposure time required for dAzaC to induce the EBV lytic cycle [12].

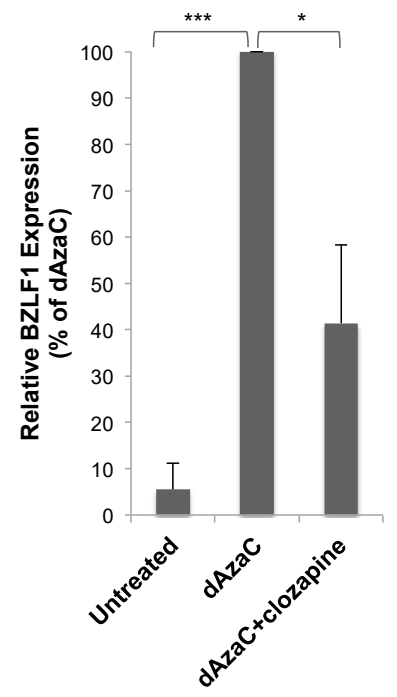

Figure 5. Clozapine decreased EBV lytic BZLF1 expression induced by 5-aza-2'-deoxycytidine (dAzaC). BZLF1 expression was measured in HH514-16 cells after treatment for $24 \mathrm{~h}$ with dAzaC $(10 \mu \mathrm{M})$ alone or combined with clozapine $(50 \mu \mathrm{M})$ and compared to untreated cells. The average of six biological replicates was plotted as a percentage of BZLF1 expression induced by dAzaC. $p$-value $<0.05$ is denoted with ${ }^{*}, p$-value $<0.001$ with ${ }^{* * *}$. 
To determine the effectiveness of clozapine as an inhibitor in a separate $\mathrm{EBV}^{+}$cell line, lytic reactivation was tested in Raji cells-a Burkitt lymphoma cell line with a different genetic background than HH514-16 cells. The lytic cycle was induced in the Raji cells by the addition of TPA $(20 \mathrm{ng} / \mathrm{mL}$ ) and detected by the expression of the EBV BRLF1 mRNA (Figure 6). When the cells were treated with clozapine $(50 \mu \mathrm{M})$ and TPA for $24 \mathrm{~h}$, the induction of BRLF1 expression was blocked. Raji cells treated with clozapine alone showed a $60 \%$ decrease, though not statistically significant, in basal levels of BRLF1 expression compared to untreated cells. These results provide evidence that clozapine inhibits EBV lytic reactivation by different classes of inducing agents and in different cell lines.

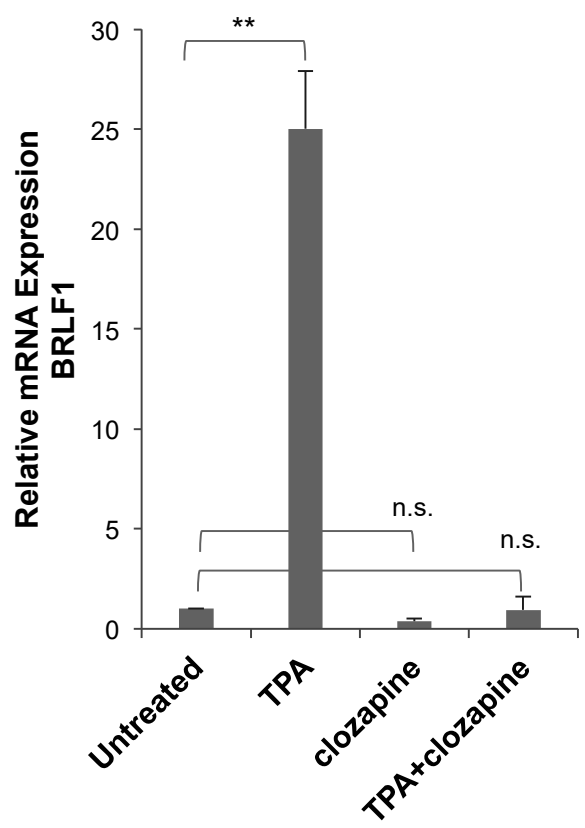

Figure 6. Clozapine inhibited EBV lytic BRLF1 expression in Raji cells. BRLF1 expression was measured in Raji cells after treatment with TPA $(20 \mathrm{ng} / \mathrm{mL})$ for $24 \mathrm{~h}$ in the absence and presence of clozapine $(50 \mu \mathrm{M})$. The average BRLF1 expression of three or more biological replicates for each of the treated conditions was compared to untreated cells. Treated conditions are marked not significantly different (n.s.) or different with $p$-value $<0.01\left({ }^{* *}\right)$ compared to untreated.

\subsection{Metabolites of Clozapine}

Two of the major metabolites of clozapine-clozapine-N-oxide (CNO) and N-desmethylclozapine (NDMC; norclozapine) [13] - were tested to determine if the effects of clozapine on EBV lytic reactivation would be altered as the drug was metabolized. Neither clozapine metabolite by itself had any effect on basal levels of BZLF1 expression in HH514-16 Burkitt lymphoma cells (Figure 7). Cells were then treated with butyrate and $\mathrm{CNO}$ at $50 \mu \mathrm{M}$ - the same concentration at which clozapine inhibited BZLF1 expression (Figures 2 and 3). The induction of BZLF1 expression by $\mathrm{NaB}$ was the same in the absence or presence of $\mathrm{CNO}$, demonstrating no inhibitory effect by $\mathrm{CNO}$ (Figure 7). However, when combined with butyrate, NDMC $(50 \mu \mathrm{M})$ decreased BZLF1 expression by $90 \%$ compared to butyrate alone. Therefore, CNO did not decrease BZLF1 expression, but clozapine and its metabolite NDMC did inhibit EBV lytic gene expression. 


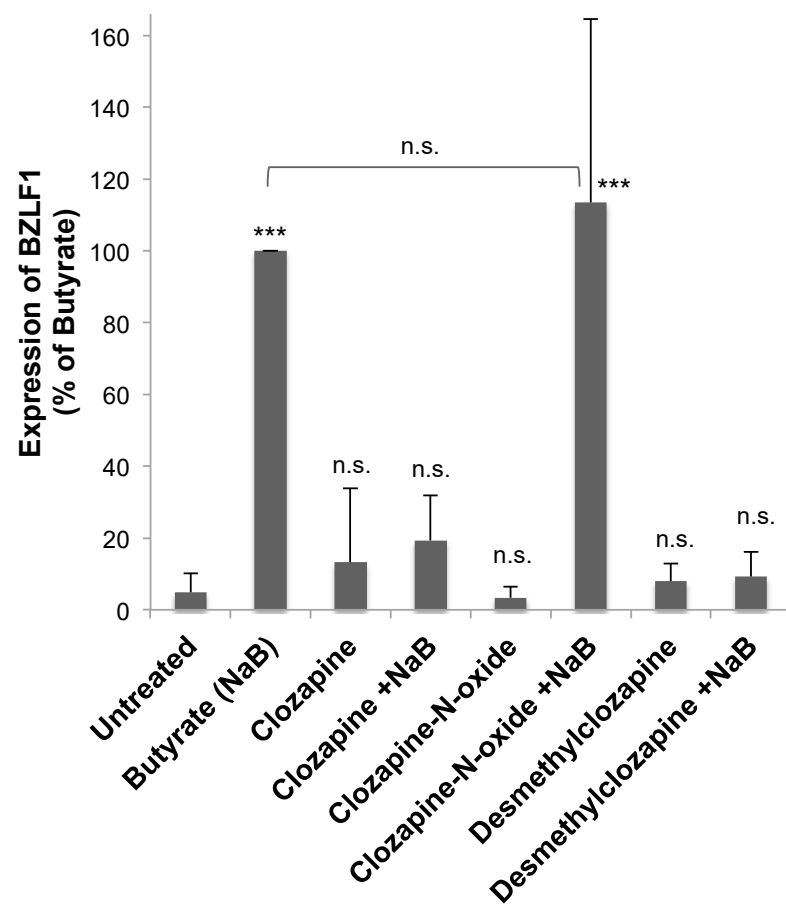

Figure 7. Desmethylclozapine, a metabolite of clozapine, inhibited EBV lytic reactivation, but clozapine-N-oxide did not. HH514-16 cells were treated with clozapine $(50 \mu \mathrm{M})$, clozapine $\mathrm{N}$-oxide $(50 \mu \mathrm{M})$, or desmethylclozapine $(50 \mu \mathrm{M})$ for $24 \mathrm{~h}$ in the presence and absence of butyrate $(\mathrm{NaB} ; 3 \mathrm{mM})$. EBV lytic reactivation was measured by the expression of BZLF1. The averaged data are plotted as a percent of the BZLF1 expression induced by NaB. Data represent the average and standard deviation of five biological replicates. Changes from untreated are marked n.s for not significant, $p$-value $<0.001$ is denoted with ${ }^{* * *}$, and $p$-value $<0.05$ with *. The $\mathrm{NaB}$ and $\mathrm{NaB}+$ clozapine- $\mathrm{N}$-oxide were not significantly different.

\section{Discussion}

\subsection{Concentrations of Clozapine in Therapeutic Use}

Clozapine, shown here to inhibit expression of EBV lytic genes, is an antipsychotic drug used to treat schizophrenia. The standard dosing for patients is $300-600 \mathrm{mg}$ of clozapine per day [14]. The recommended therapeutic range for clozapine plasma levels range from 350-550 ng/mL for effective treatment. The actual concentrations vary by patient, with factors such as weight and whether the patient smokes influencing this greatly. Studies of patients taking $400 \mathrm{mg} /$ day of clozapine have measured blood concentrations of 40-1911 ng/mL and $84-1088 \mathrm{ng} / \mathrm{mL}$ [15]. The maximum plasma level recommended varies between 600 and $2000 \mathrm{ng} / \mathrm{mL}$ [16]. The clozapine concentration that inhibited EBV was $50 \mu \mathrm{M}$ (Figure 3), which is $\sim 8-16$-fold higher than plasma concentrations in patients. In experiments conducted in vitro, concentrations of clozapine up to $50 \mu \mathrm{M}$ had no effect on the viability of HH514-16 Burkitt lymphoma cell line (Figure 5). In another study that used a modified tetrazolium assay to assess the viability of U-937 cells from a patient with histiocytic lymphoma, clozapine had no effect on cell survival after $24 \mathrm{~h}$ of treatment with $6250 \mathrm{ng} / \mathrm{mL}(19 \mu \mathrm{M})$ clozapine, and $80 \%$ of cells survived when exposed to $12,500 \mathrm{ng} / \mathrm{mL}(\sim 40 \mu \mathrm{M})$ clozapine [17]. No toxicity was observed by clozapine at $>50 \mu \mathrm{M}$ in neutrophils, monocytes, or HL-60 human leukemia cells [18].

\subsection{Metabolites of Clozapine}

The metabolism of clozapine is catalyzed by the cytochrome P450 enzymes in the liver into two main metabolites: clozapine-n-oxide (CNO) and N-desmethylclozapine (NDMC). NDMC is found in patient plasma at concentrations similar to clozapine, while $\mathrm{CNO}$ is much less [13]. CNO is 
pharmacologically inactive, but has the potential to reverse-metabolize into its parent compound clozapine [19]. No therapeutic benefits of NDMC have been demonstrated for the treatment of schizophrenia [20], but it does have biological effects. While clozapine is an antagonist of the dopamine $\mathrm{D}_{2}$ receptor, NDMC is a partial agonist in some assays [21]. NDMC is an allosteric agonist at the muscarinic M1 receptor. The muscarinic agonist activity of NDMC can potentiate N-methyl-D-aspartate (NMDA) receptor currents [22]. NDMC has a higher affinity for 5- $\mathrm{HT}_{1 \mathrm{C}}$ and 5- $\mathrm{HT}_{2}$ receptors than clozapine, while CNO is less potent [23]. NDMC is more effective than clozapine as a partial agonist of the $5-\mathrm{HT}_{1 \mathrm{C}}$ receptor [21]. At higher concentrations, clozapine and $\mathrm{NDMC}$, but not $\mathrm{CNO}$, also antagonize the $\mathrm{GABA}_{\mathrm{A}}$ receptor [24]. Overall, clozapine and NDMC are more biologically active than CNO, which correlates with the observed effects on EBV lytic reactivation where clozapine and NDMC inhibited EBV, but CNO did not (Figure 7).

\subsection{The Effects of Clozapine on Immune Cells}

One of the most potentially critical side effects of clozapine is agranulocytosis-a reduction in granule-containing white blood cells, particularly neutrophils. Due to the potential for agranulocytosis and a high risk of infection, patients taking clozapine require long-term hematology monitoring. A number of mechanisms for the clozapine-induced agranulocytosis have been explored [25,26]. In macrophages, clozapine affects adhesion, phagocytosis, and reactive oxygen species production [27]. Clozapine also alters cytokine production in macrophages [27]. Effects of clozapine on cytokine production have been observed in a number of studies on peripheral blood mononuclear cells or whole blood and in patients with schizophrenia, though reported results have varied, and even contradicted, possibly due to varying cell sources and treatment conditions [28]. Clozapine suppresses interferon- $\gamma$ production in peripheral blood mononuclear cells and inhibits Th1 cell differentiation [29]. Clozapine inhibits the production of the T-bet transcription factor and enhances mRNA expression of STAT6 and GATA3 [29]. Whole-genome analysis using the T lymphocyte cell line JM-Jurkat treated with clozapine revealed changes in expression of hundreds of mRNAs and miRNAs involved in a number of cellular processes, including cellular metabolism and oxidative stress [30]. The effects of clozapine on B cells have been less well studied.

\subsection{Mechanism of Action}

The first-generation, or typical, antipsychotic drugs are high-affinity antagonists of the dopamine $\mathrm{D}_{2}$ receptor. However, the extrapyramidal symptoms (EPSs), such as involuntary movement and muscle control, caused by typical antipsychotics have been attributed to potent dopamine antagonism [31]. The second-generation, atypical, anti-psychotic drugs such as clozapine have less affinity for the $\mathrm{D}_{2}$ receptors and result in reduced EPS side effects. Atypical drugs also target other dopamine receptors $\left(D_{1}\right.$, $\mathrm{D}_{3}, \mathrm{D}_{4}$ ), the 5- $\mathrm{HT}_{1 \mathrm{~A}}, 5-\mathrm{HT}_{2 \mathrm{~A}}, 5-\mathrm{HT}_{2 \mathrm{C}}, 5-\mathrm{HT}_{6}$, and 5- $\mathrm{HT}_{7}$ receptors for serotonin (5-hydroxytryptamine), as well as muscarinic, adrenergic, and histamine receptors [32]. Clozapine has a high affinity for the serotonin $5-\mathrm{HT}_{2 \mathrm{~A}}$ receptor [33,34]. A theory on the effectiveness of atypical antipsychotics relates a higher ratio of a drug's affinity for the $5-\mathrm{HT}_{2 \mathrm{~A}}$ receptor compared to the dopamine $\mathrm{D}_{2}$ receptor. The $5-\mathrm{HT}_{1 \mathrm{~A}}$ receptor may also play a role in the antipsychotic effect, as the receptor is stimulated by clozapine and other antipsychotic drugs [35]. Serotonin is not only active in the nervous system, but also affects the immune system. Serotonin increases the mitogen-stimulated proliferation of B-cells, which is dependent on the serotonin $5-\mathrm{HT}_{1 \mathrm{~A}}$ receptor [36]. The 5- $\mathrm{HT}_{3 \mathrm{~A}}$ receptor is expressed on B-cells and is differentially expressed in diffuse large B-cell lymphomas (DLBCL) compared to non-neoplastic B cells [37]. The serotonin transporter (SERT) is also expressed on B cells. Culturing Burkitt lymphoma cell lines with serotonin leads to increased serotonin uptake by SERT, decreased DNA synthesis, and apoptosis of Burkitt lymphoma cells, including in EBV-positive cells [38].

The mechanism of action of VPA as an inhibitor of EBV lytic reactivation in lymphoma cells is not known $[4,39]$. VPA is known to have a number of effects in neurons, however, which of these roles is responsible for the clinical effects of this drug in neurological disorders is uncertain [40]. The proposed 
mechanisms of VPA and clozapine are not similar, and they do not have a similar chemical structure, so it is possible that the two drugs affect EBV lytic reactivation in different ways. The cellular targets of antipsychotic, anti-epileptic, and mood-stabilizing drugs will continue to be explored in cells infected by EBV.

\subsection{Effect of Clozapine and Its Metabolites on Other Viruses}

The clozapine metabolite $\mathrm{N}$-desmethylclozapine was found to inhibit replication of dengue virus (DENV) [41]. The inhibition of N-desmethylclozapine was specific to DENV. It did not have an effect on other flaviviruses (i.e., Japanese encephalitis virus, West Nile virus), or on the RNA viruses respiratory syncytial virus and rotavirus. Inhibition occurred at an early step in the viral life cycle prior to viral replication. Two other metabolites of clozapine, 8-OH-deschloro-clozapine and 8-OH-desmethylclozapine, inhibit human immunodeficiency virus (HIV) type 1 [42]. Neither clozapine, the primary compound, nor desmethylclozapine show any antiviral effects, suggesting that inhibition of HIV is due to the metabolism of clozapine. Clozapine $(30 \mu \mathrm{M})$ decreased the infection of a human glial cell line by the human polyomavirus JC virus by approximately one-half [43]. The human endogenous retroviruses (HERVs) are associated with schizophrenia and other neurological diseases. Clozapine had no significant effect on the transcription of HERVs in three types of brain cell lines, though VPA upregulated the transcription of many HERVs [44]. Valpromide, an anti-epileptic drug that inhibits EBV lytic reactivation [5], had no effect on vesicular stomatitis virus infection [45]. Valpromide and a structurally-related molecule valnoctamide inhibited infection and replication of the human herpesvirus cytomegalovirus in cell culture, and increased the survival rate of mice infected with mouse cytomegalovirus [45].

In conclusion, the repurposing of antipsychotic drugs as antivirals has the potential for therapeutic use. Understanding how clozapine inhibits EBV may lead to the discovery of cellular pathways that regulate the latent-lytic switch of the virus. Future studies will be aimed at determining the effects of other antipsychotic drugs on EBV lytic reactivation and identifying common molecular targets in cells that may provide information about the mechanisms important in neurological disease and for the viral life cycle.

Author Contributions: K.L.G conceived the research and designed the experiments; A.G.A., C.B.G., and J.R.W. performed the experiments; K.L.G., A.G.A., and C.B.G. analyzed the data; K.L.G. did the statistical analysis; K.L.G., A.G.A., and J.R.W. wrote the paper; K.L.G. edited the paper.

Acknowledgments: We thank McKenna Theine, Jenna Hayes, and Kayla Feehan for technical assistance. This work was funded by the UWL College of Science and Health and UWL Faculty Research Grants to K.L.G., the UWL Eagle Apprentice Program for J.R.W., and UWL Undergraduate Research and Creativity grants to A.G.A. and C.B.G.

Conflicts of Interest: The authors declare no conflict of interest.

\section{References}

1. Miller, G.; El-Guindy, A.; Countryman, J.; Ye, J.; Gradoville, L. Lytic Cycle Switches of Oncogenic Human Gammaherpesviruses1. Adv. Cancer Res. 2007, 97, 81-109. [PubMed]

2. Luka, J.; Kallin, B.; Klein, G. Induction of the Epstein-Barr virus (EBV) cycle in latently infected cells by n-butyrate. Virology 1979, 94, 228-231. [CrossRef]

3. Ben-Ssson, S.A.; Klein, G. Activation of the epstein-barr virus genome by 5-aza-cytidine in latently infected human lymphoid lines. Int. J. Cancer 1981, 28, 131-135. [CrossRef]

4. Tuck, D.; Gradoville, L.; Daigle, D.; Gorres, K.; Wang'ondu, R.; Miller, G.; Schulz, V.; Ye, J. Valproic Acid Antagonizes the Capacity of Other Histone Deacetylase Inhibitors To Activate the Epstein-Barr Virus Lytic Cycle. J. Virol. 2011, 85, 5628-5643.

5. Gorres, K.L.; Daigle, D.; Mohanram, S.; McInerney, G.E.; Lyons, D.E.; Miller, G. Valpromide Inhibits Lytic Cycle Reactivation of Epstein-Barr Virus. MBio 2016, 7, e00113. [CrossRef]

6. Wenthur, C.J.; Lindsley, C.W. Classics in chemical neuroscience: Clozapine. ACS Chem. Neurosci. 2013, 4, 1018-1025. [CrossRef] 
7. Nucifora, F.C.; Mihaljevic, M.; Lee, B.J.; Sawa, A. Clozapine as a Model for Antipsychotic Development. Neurotherapeutics 2017, 14, 750-761. [CrossRef]

8. Heston, L.; Rabson, M.; Brown, N.; Miller, G. New Epstein-Barr virus variants from cellular subclones of P3J-HR-1 Burkitt lymphoma. Nature 1982, 295, 160-163. [CrossRef]

9. Countryman, J.; Jenson, H.; Seibl, R.; Wolf, H.; Miller, G. Polymorphic proteins encoded within BZLF1 of defective and standard Epstein-Barr viruses disrupt latency. J. Virol. 1987, 61, 3672-3679. [PubMed]

10. Kenney, S.; Holley-Guthrie, E.; Mar, E.C.; Smith, M. The Epstein-Barr virus BMLF1 promoter contains an enhancer element that is responsive to the BZLF1 and BRLF1 transactivators. J. Virol. 1989, 63, 3878-3883.

11. Buisson, M.; Manet, E.; Trescol-Biemont, M.C.; Gruffat, H.; Durand, B.; Sergeant, A. The Epstein-Barr virus (EBV) early protein EB2 is a posttranscriptional activator expressed under the control of EBV transcription factors EB1 and R. J. Virol. 1989, 63, 5276-5284. [PubMed]

12. Himmelfarb, S.; Bhaduri-McIntosh, S.; Gradoville, L.; Heston, L.; Miller, G.; Ye, J.; Shedd, D.; Countryman, J. Stimulus Duration and Response Time Independently Influence the Kinetics of Lytic Cycle Reactivation of Epstein-Barr Virus. J. Virol. 2009, 83, 10694-10709.

13. Centorrino, F.; Baldessarini, R.J.; Kando, J.C.; Frankenburg, F.R.; Volpicelli, S.A.; Flood, J.G. Clozapine and metabolites: concentrations in serum and clinical findings during treatment of chronically psychotic patients. J. Clin. Psychopharmacol. 1994, 14, 119-125. [CrossRef]

14. Subramanian, S.; Völlm, B.A.; Huband, N. Clozapine dose for schizophrenia. Cochrane Database Syst. Rev. 2017, 2017. [CrossRef] [PubMed]

15. Mauri, M.C.; Volonteri, L.S.; Colasanti, A.; Fiorentini, A.; De Gaspari, I.F.; Bareggi, S.R. Clinical Pharmacokinetics of Atypical Antipsychotics A Critical Review of the Relationship Between Plasma Concentrations and Clinical Response. Clin. Pharmacokinet. 2007, 46, 359-388. [CrossRef]

16. Stark, A.; Scott, J. A review of the use of clozapine levels to guide treatment and determine cause of death. Aust. New Zeal. J. Psychiatry 2012, 46, 816-825. [CrossRef]

17. Heiser, P.; Enning, F.; Krieg, J.-C.; Vedder, H. Effects of haloperidol, clozapine and olanzapine on the survival of human neuronal and immune cells. J. Psychopharmacol. 2007, 21, 851-856. [CrossRef]

18. Gardner, I.; Leeder, J.S.; Chin, T.; Zahid, N.; Uetrecht, J.P. A comparison of the covalent binding of clozapine and olanzapine to human neutrophils in vitro and in vivo. Mol. Pharmacol. 1998, 53, 999-1008.

19. Chang, W.-H.; Lin, S.-K.; Lane, H.-Y.; Wei, F.-C.; Hu, W.-H.; Lam, Y.F.; Jann, M.W. Reversible metabolism of clozapine and clozapine N-oxide in schizophrenic patients. Prog. Neuro-Psychopharmacol. Biol. Psychiatry 1998, 22, 723-739. [CrossRef]

20. Ghosh, A.; Chakraborty, K.; Mattoo, S.K. Newer molecules in the treatment of schizophrenia: A clinical update. Indian J. Pharmacol. 2011, 43, 105-112.

21. Heusler, P.; Bruins Slot, L.; Tourette, A.; Tardif, S.; Cussac, D. The clozapine metabolite N-desmethylclozapine displays variable activity in diverse functional assays at human dopamine D 2 and serotonin 5-HT 1A receptors. Eur. J. Pharmacol. 2011, 669, 51-58. [CrossRef]

22. Sur, C.; Mallorga, P.J.; Wittmann, M.; Jacobson, M.A.; Pascarella, D.; Williams, J.B.; Brandish, P.E.; Pettibone, D.J.; Scolnick, E.M.; Conn, P.J. N-desmethylclozapine, an allosteric agonist at muscarinic 1 receptor, potentiates N-methyl- D-aspartate receptor activity. Proc. Natl. Acad. Sci. USA 2003, 100, 13674-13679. [CrossRef]

23. Kuoppamäki, M.; Syvälahti, E.; Hietala, J. Clozapine and N-desmethylclozapine are potent 5-HT1C receptor antagonists. Eur. J. Pharmacol. 1993, 245, 179-182. [CrossRef]

24. Kuoppamiiki, M.; Liiddens, H.; Syviilahti, E. Effects of clozapine metabolites and chronic clozapine treatment on rat brain. Eur. J. Pharmacol. 1996, 314, 319-323.

25. Numata, S.; Umehara, H.; Ohmori, T.; Hashimoto, R. Clozapine Pharmacogenetic Studies in Schizophrenia: Efficacy and Agranulocytosis. Front. Pharmacol. 2018, 9, 1049. [CrossRef]

26. Wiciński, M.; Węclewicz, M.M. Clozapine-induced agranulocytosis/granulocytopenia. Curr. Opin. Hematol. 2018, 25, 22-28. [CrossRef]

27. Chen, M.-L.; Wu, S.; Tsai, T.-C.; Wang, L.-K.; Tsai, F.-M. Regulation of macrophage immune responses by antipsychotic drugs. Immunopharmacol. Immunotoxicol. 2013, 35, 573-580. [CrossRef]

28. Røge, R.; Møller, B.K.; Andersen, C.R.; Correll, C.U.; Nielsen, J. Immunomodulatory effects of clozapine and their clinical implications: What have we learned so far? Schizophr. Res. 2012, 140, 204-213. [CrossRef] 
29. Chen, M.-L.; Tsai, T.-C.; Wang, L.-K.; Lin, Y.-Y.; Tsai, Y.-M.; Lee, M.-C.; Tsai, F.-M. Clozapine inhibits Th1 cell differentiation and causes the suppression of IFN- $\gamma$ production in peripheral blood mononuclear cells. Immunopharmacol. Immunotoxicol. 2012, 34, 686-694. [CrossRef]

30. Gardiner, E.; Carroll, A.; Tooney, P.A.; Cairns, M.J. Antipsychotic drug-associated gene-miRNA interaction in T-lymphocytes. Int. J. Neuropsychopharmacol. 2014, 17, 929-943. [CrossRef]

31. Divac, N.; Prostran, M.; Jakovcevski, I.; Cerovac, N. Second-Generation Antipsychotics and Extrapyramidal Adverse Effects. Biomed Res. Int. 2014, 2014, 1-6. [CrossRef]

32. Aringhieri, S.; Carli, M.; Kolachalam, S.; Verdesca, V.; Cini, E.; Rossi, M.; McCormick, P.J.; Corsini, G.U.; Maggio, R.; Scarselli, M. Molecular targets of atypical antipsychotics: From mechanism of action to clinical differences. Pharmacol. Ther. 2018, 192, 20-41. [CrossRef] [PubMed]

33. Meltzer, H.Y. What's atypical about atypical antipsychotic drugs? Curr. Opin. Pharmacol. 2004, 4, 53-57. [CrossRef]

34. Kuroki, T.; Nagao, N.; Nakahara, T. Neuropharmacology of second-generation antipsychotic drugs: a validity of the serotonin-dopamine hypothesis. Prog. Brain Res. 2008, 172, 199-212.

35. Meltzer, H.; Massey, B. The role of serotonin receptors in the action of atypical antipsychotic drugs. Curr. Opin. Pharmacol. 2011, 11, 59-67. [CrossRef]

36. Iken, K.; Chheng, S.; Fargin, A.; Goulet, A.-C.; Kouassi, E. Serotonin Upregulates Mitogen-Stimulated B Lymphocyte Proliferation through 5-HT1AReceptors. Cell. Immunol. 1995, 163, 1-9. [CrossRef] [PubMed]

37. Rinaldi, A.; Chiaravalli, A.M.; Mian, M.; Zucca, E.; Tibiletti, M.G.; Capella, C.; Bertoni, F. Serotonin Receptor 3A Expression in Normal and Neoplastic B Cells. Pathobiology 2010, 77, 129-135. [CrossRef] [PubMed]

38. Serafeim, A.; Grafton, G.; Chamba, A.; Gregory, C.D.; Blakely, R.D.; Bowery, N.G.; Barnes, N.M.; Gordon, J. 5-Hydroxytryptamine drives apoptosis in biopsylike Burkitt lymphoma cells: Reversal by selective serotonin reuptake inhibitors. Blood 2002, 99, 2545-2553. [CrossRef]

39. Gorres, K.L.; Daigle, D.; Mohanram, S.; Miller, G. Activation and Repression of Epstein-Barr Virus and Kaposi's Sarcoma-Associated Herpesvirus Lytic Cycles by Short- and Medium-Chain Fatty Acids. J. Virol. 2014, 88, 8028-8044. [CrossRef]

40. Monti, B.; Polazzi, E.; Contestabile, A. Biochemical, Molecular and Epigenetic Mechanisms of Valproic Acid Neuroprotection. Curr. Mol. Pharmacol. 2010, 2, 95-109. [CrossRef]

41. Medigeshi, G.R.; Kumar, R.; Dhamija, E.; Agrawal, T.; Kar, M. N-Desmethylclozapine, Fluoxetine, and Salmeterol Inhibit Postentry Stages of the Dengue Virus Life Cycle. Antimicrob. Agents Chemother. 2016, 60, 6709-6718. [CrossRef]

42. Jones-Brando, L.V.; Buthod, J.L.; Holland, L.E.; Yolken, R.H.; Fuller Torrey, E. Metabolites of the antipsychotic agent clozapine inhibit the replication of human immunodeficiency virus type 1. Schizophr. Res. 1997, 25, 63-70. [CrossRef]

43. Baum, S.; Ashok, A.; Gee, G.; Dimitrova, S.; Querbes, W.; Jordan, J.; Atwood, W.J. Early events in the life cycle of JC virus as potential therapeutic targets for the treatment of progressive multifocal leukoencephalopathy. J. Neurovirol. 2003, 9, 32-37. [CrossRef] [PubMed]

44. Diem, O.; Schäffner, M.; Seifarth, W.; Leib-Mösch, C. Influence of Antipsychotic Drugs on Human Endogenous Retrovirus (HERV) Transcription in Brain Cells. PLoS ONE 2012, 7, e30054. [CrossRef] [PubMed]

45. Ornaghi, S.; Davis, J.N.; Gorres, K.L.; Miller, G.; Paidas, M.J.; van den Pol, A.N. Mood stabilizers inhibit cytomegalovirus infection. Virology 2016, 499, 121-135. [CrossRef]

(C) 2019 by the authors. Licensee MDPI, Basel, Switzerland. This article is an open access article distributed under the terms and conditions of the Creative Commons Attribution (CC BY) license (http://creativecommons.org/licenses/by/4.0/). 